Open Access

\title{
Association of Insulin-like growth factor binding protein 2 genotypes with growth, carcass and meat quality traits in pigs
}

Sombat Prasongsook ${ }^{1}$, Igseo Choi ${ }^{2,3}$, Ronald O. Bates ${ }^{2}$, Nancy E. Raney ${ }^{2}$, Catherine W. Ernst ${ }^{2}$ and Sornthep Tumwasorn ${ }^{1 *}$

\begin{abstract}
Background: This study was conducted to investigate the potential association of variation in the insulin-like growth factor binding protein 2 (IGFBP2) gene with growth, carcass and meat quality traits in pigs. IGFBP2 is a member of the insulin-like growth factor binding protein family that is involved in regulating growth, and it maps to a region of pig chromosome 15 containing significant quantitative trait loci that affect economically important trait phenotypes.

Results: An IGFBP2 polymorphism was identified in the Michigan State University (MSU) Duroc $\times$ Pietrain $F_{2}$ resource population $(n=408)$, and pigs were genotyped by Mspl PCR-RFLP. Subsequently, a Duroc pig population from the National Swine Registry, USA, $(n=326)$ was genotyped using an Illumina Golden Gate assay. The IGFBP2 genotypic frequencies among the MSU resource population pigs were $3.43,47.06$ and $49.51 \%$ for the $A A, A B$ and $B B$ genotypes, respectively. The genotypic frequencies for the Duroc pigs were $9.82,47.85$, and $42.33 \%$ for the $A A, A B$ and BB genotypes, respectively. Genotype effects $(P<0.05)$ were found in the MSU resource population for backfat thickness at $10^{\text {th }}$ rib and last rib as determined by ultrasound at $10,13,16$ and 19 weeks of age, ADG from 10 to 22 weeks of age, and age to reach $105 \mathrm{~kg}$. A genotype effect $(P<0.05)$ was also found for off test Longissimus muscle area in the Duroc population. Significant effects of IGFBP2 genotype $(P<0.05)$ were found for drip loss, $24 \mathrm{~h}$ postmortem $\mathrm{pH}$, pH decline from $45 \mathrm{~min}$ to $24 \mathrm{~h}$ postmortem, subjective color score, CIE $L^{*}$ and $b^{*}$, Warner-Bratzler shear force, and sensory panel scores for juiciness, tenderness, connective tissue and overall tenderness in MSU resource population pigs. Genotype effects $(P<0.05)$ were found for $45-\mathrm{min} \mathrm{pH}, \mathrm{CIE} \mathrm{L}^{*}$ and color score in the Duroc population.
\end{abstract}

Conclusions: Results of this study revealed associations of the IGFBP2 genotypes with growth, carcass and meat quality traits in pigs. The results indicate IGFBP2 as a potential candidate gene for growth rate, backfat thickness, loin muscle area and some pork quality traits.

Keywords: IGFBP2, Growth, Meat quality, Pig

\footnotetext{
* Correspondence: sornthep13@hotmail.com

${ }^{1}$ Department of Animal Science, Kasetsart University, Bangkok 10900,

Thailand

Full list of author information is available at the end of the article
}

() Biomed Central

(c) 2015 Prasongsook et al. Open Access This article is distributed under the terms of the Creative Commons Attribution 4.0 International License (http://creativecommons.org/licenses/by/4.0/), which permits unrestricted use, distribution, and reproduction in any medium, provided you give appropriate credit to the original author(s) and the source, provide a link to the Creative Commons license, and indicate if changes were made. The Creative Commons Public Domain Dedication waiver (http://creativecommons.org/publicdomain/zero/1.0/) applies to the data made available in this article, unless otherwise stated. 


\section{Background}

For a long time, pig breeding programs have focused mainly on reducing the costs. Selection has been aimed at increasing litter size and weight gain, decreasing backfat thickness and improving feed conversion. Now, breeding goals have begun to change and are directed much more toward retail carcass yield and meat quality because of the high economic value of these traits. Genetic improvement for valuable cuts of appropriate quality requires estimates of genetic parameters [1]. The consumption of pork has also changed from quantity to quality with the living standard of city and country residents heightened, resulting in high quality pork becoming one of the main objectives that breeders and producers pursue in breeding.

Many fattening pigs are produced through terminal crossing systems, and the Duroc or Pietrain breeds are commonly used as terminal sires. In general, pigs of the Duroc breed have been found to grow faster, but also to have more backfat than other breeds [2]. The Pietrain breed has also been used for terminal sires, and they have been shown to be leaner with a slower rate of fatty tissue deposition when compared to other breeds [3]. Molecular genetics is a popular tool used in applied science as additional information to selection, yielding more accuracy and faster genetic response to selection [4]. The development of a selection criterion for swine that can be measured early in life and can accurately predict future growth would aid in selection by allowing producers to decrease production cost and time.

The insulin-like growth factor binding protein 2 (IGFBP2) is a member of the IGFBP family. Previous studies reported the association of the IGFBP2 gene with some carcass and body composition traits in farm animals [5-7]. Several significant QTL have been identified on Sus scrofa chromosome 15 (SSC15) in the region where $I G B F P 2$ is located with effects on meat quality traits $[8,9]$. Moreover, Edwards et al. [10] also found significant QTL affecting meat color and tenderness on SSC15 in the MSU Duroc $\times$ Pietrain $F_{2}$ resource population. In addition, Wang et al. [7] reported the association of an IGFBP2 polymorphism defined using the PCR-SSCP technique, with production performance in a Lantang $\times$ Landrace pig population, and they found that different IGFBP2 haplotypes were associated with meat color and marbling. For growth traits, a previous study found a significant QTL on SSC15 with effect on average daily gain from birth to 70 days in a crossbred wild boar $\times$ Large White pig population [11]. However, research on the association of IGFBP2 polymorphisms with carcass and meat quality traits in pigs is limited. Consequently, IGFBP2 has been selected as a candidate gene for further study on its potential effects.

\section{Methods}

Experimental populations and management MSU Duroc $\times$ Pietrain resource population

The Michigan State University (MSU) Duroc $\times$ Pietrain resource population was used in this study. This population was established by crossing 4 Duroc sires with 15 Pietrain dams $\left(\mathrm{F}_{0}\right)$, and $6 \mathrm{~F}_{1}$ sires and $50 \mathrm{~F}_{1}$ dams were retained to propagate the $F_{2}$ generation. The $F_{1}$ pigs were intercrossed and $408 \mathrm{~F}_{2}$ pigs were used in this study. Pigs were weaned at 16 to 25 days of age and then sorted into nursery pens by sex and weight. At 10 weeks of age, $F_{2}$ pigs were placed into finishing pens. All $\mathrm{F}_{2}$ pigs had ad libitum access to feed and water, and commercial corn-soybean-based diets that met or exceeded all NRC requirements [12]. Further details of the population and animal management are found in Edwards et al. [13].

\section{Commercial Duroc population}

A purebred Duroc population including pigs from three herds obtained from the National Swine Registry (NSR; http://www.nationalswine.com) in the United States was used to further investigate the effect of the IGFBP2 polymorphism on growth and meat quality traits. Three sire families were sampled per herd with approximately 40 pigs per sire family. Sires were chosen to represent a cross-section of the Duroc sire families within the USA. In each herd, pigs were removed from growth test as they approached $113 \mathrm{~kg}$, weighed and had $10^{\text {th }} \mathrm{rib}$ backfat thickness and loin muscle area estimated using B-mode ultrasound. Further details on the population can be found in Choi et al. [14].

\section{Phenotypic measurements}

\section{MSU Duroc $\times$ Pietrain $F_{2}$ resource population}

Phenotypic data for 25 growth traits for $408 \mathrm{~F}_{2}$ pigs from the MSU resource population was used for this study. Body weight was measured at birth, weaning, 6, 10, 13, 16, 19 and 22 weeks of age, and average daily gain from 10 to 22 weeks of age (ADG) and days to $105 \mathrm{~kg}$ were calculated. B-mode ultrasound (Pie Medical 200SLC, Classic Medical Supply, Inc., Tequesta, FL, USA.) estimates of $10^{\text {th }}$ backfat thickness (BF10), last rib backfat thickness (LRF), and Longissimus muscle area (LMA) were recorded at 10, 13, 16, 19 and 22 weeks of age. Collection of phenotypic data was previously described in Edwards et al. [13].

When pigs reached market weight $(113.03 \pm 8.69 \mathrm{~kg})$, they were transported to one of 2 abattoirs, either the Michigan State University Meat Laboratory (East Lansing, MI) or a small federally inspected plant in western Michigan (DeVries Meats, Coopersville, MI). All pigs were fasted overnight but had ad libitum access to water. Postmortem carcass traits recorded 
included hot carcass weight, Longissimus muscle (LM) $\mathrm{pH}$ and temperature at $45 \mathrm{~min}(45-\mathrm{min} \mathrm{pH}$ and $45-\mathrm{min}$ temp), $\mathrm{LM} \mathrm{pH}$ and temperature at $24 \mathrm{~h}$ (24-h $\mathrm{pH}$ and 24-h temp), dressing percent, $\mathrm{pH}$ decline from $45 \mathrm{~min}$ to $24 \mathrm{~h}$ postmortem ( $\mathrm{pH}$ decline), first rib backfat thickness, last rib backfat thickness, $10^{\text {th }}$ rib backfat thickness, last lumbar vertebra backfat thickness, number of ribs, carcass length, Longissimus muscle area at the $10^{\text {th }}$ rib (LMA) and primal cut weights (ham, trimmed loin, picnic shoulder, Boston shoulder, belly and spareribs). Meat quality measurements included subjective color score, firmness score, marbling score, objective color values of CIE L* (lightness), a* (redness) and $\mathrm{b}^{*}$ (yellowness) measured using a Minolta CR-310 colorimeter (Ramsey, NJ), drip loss, Warner-Bratzler shear force (WBS) and sensory panel evaluation (juiciness, muscle fiber and overall tenderness, connective tissue, and off-flavor). Further details of phenotypic data collection are found in Edwards et al. [10].

\section{Commercial Duroc population}

Three growth traits were recorded for pigs from the Duroc population including $10^{\text {th }}$ rib backfat thickness and Longissimus muscle area adjusted to $113 \mathrm{~kg}$ live weight, and days of age to reach $113 \mathrm{~kg}$. Adjustments were calculated based on the NSIF guidelines [15].

Soon after growth test completion, pigs were harvested through a commercial packing plant where meat quality traits were recorded. The meat quality traits were 45-min $\mathrm{pH}, 24-\mathrm{h} \mathrm{pH}, \mathrm{pH}$ decline, objective color $\left(\mathrm{CIE} \mathrm{L}^{*}\right)$, subjective color score and marbling score. Further details of phenotypic data collection are found in Choi et al. [14].

\section{Genotypic data collection MSU Duroc $\times$ Pietrain $F_{2}$ resource population}

\section{PCR-RFLP assays}

Genomic DNA was isolated from venous blood collected in EDTA. The PCR was carried out with $10 \mathrm{ng}$ of genomic DNA. Primers (forward 5'-GGTCTGATTGGAG GG GT GT-3'; reverse 5' -AGCCAAGGAGAAATGTG AA GG-3') were designed to amplify a 245 bp fragment of intron 2 of the porcine IGFBP2 gene. Identity of this fragment was confirmed by DNA sequencing (ABI PRISM $^{\circ} 3100$ Genetic Analyzer, Applied Biosystems, Foster City, CA, USA), and sequence of the sequence tagged site (STS) was submitted to the NCBI database (GenBank Accession No. BV727778).

The PCR was performed in a final volume of $10 \mu \mathrm{L}$ containing $1 \mu \mathrm{L}$ of genomic DNA $(10 \mathrm{ng} / \mu \mathrm{L}), 1 \mu \mathrm{L}$ of each primer $(5 \mu \mathrm{M}), 0.1 \mu \mathrm{L}$ of deoxynucleotide triphosphates $(25 \mu \mathrm{M})$ mixture, $0.6 \mu \mathrm{L}$ of $\mathrm{MgCl}_{2}(25 \mathrm{mM})$, $0.1 \mu \mathrm{L}$ of DNA polymerase $(5 \mathrm{U} / \mu \mathrm{L}), 1 \mu \mathrm{L}$ of $10 \mathrm{X}$ reaction buffer and $5.2 \mu \mathrm{L}$ of water on a PTC-200 thermal cycler (MJ research, Watertown, MA, USA). The following PCR profile was used: initial denaturation at $94{ }^{\circ} \mathrm{C}$ for $3 \mathrm{~min}$; 30 cycles of $94{ }^{\circ} \mathrm{C}$ for $1 \mathrm{~min}$ (denaturation), $60{ }^{\circ} \mathrm{C}$ for $1 \mathrm{~min}$ (annealing) and $72{ }^{\circ} \mathrm{C}$ for $1 \mathrm{~min}$ (extension), and $72{ }^{\circ} \mathrm{C}$ for $10 \mathrm{~min}$ (final elongation).

The IGFBP2 PCR products were digested using MspI restriction endonuclease at $37{ }^{\circ} \mathrm{C}$ overnight. The restriction digests were electrophoresed for $1.5 \mathrm{~h}$ at $95 \mathrm{~V}$ on a $2.0 \%$ agarose gel with ethidium bromide in $1 \mathrm{X}$ TBE buffer. Individual PCR-RFLP fragment sizes were determined by visualizing the band pattern under ultraviolet light. Three genotypes were detected and defined as $\mathrm{AA}, \mathrm{AB}$, and $\mathrm{BB}$. The MspI-digested PCR products had fragment sizes of 245 bp for the AA genotype (non $M s p$ I recognition site), 190 and 55 bp for the BB genotype, and a combination of 245,190 and 55 bp for the $\mathrm{AB}$ genotype (Fig. 1).

\section{Commercial Duroc population}

Genomic DNA was isolated from muscle tissue collected at harvest using a PureLink Genomic DNA kit (Invitrogen, Carlsbad, CA, USA). The IGFBP2 marker identified by PCR-RFLP was included in an Illumina Goldengate 96 plex SNP multiplex custom assay panel [14], and genotyping of IGFBP2 for pigs from the Duroc population was performed at the MSU Research Technology Support Facility. Genotype segregation to identify pigs as $\mathrm{AA}, \mathrm{AB}$ or $\mathrm{BB}$ was determined using the Illumina Genome Studio software.

\section{Allele and genotype frequency, and genetic linkage analyses}

Allele and genotype frequencies for the IGFBP2 polymorphism were estimated by the FREQ procedure of SAS (SAS 9.0, SAS Institute, Cary, NC, USA), and Hardy-Weinberg equilibrium (HWE) was tested by $\chi^{2}$. Genetic linkage analysis of the MSU Duroc $\times$ Pietrain resource population was performed using CRIMAP software version $2.4[16]$.

\section{Statistical analysis}

The datasets were analyzed by the MIXED procedure of SAS (SAS 9.0, SAS Institute, Cary, NC, USA). The genotype effect within each model was tested with an F-test. If the F-test was significant, $t$-tests were used to determine significance between estimates of least square means (LSMeans) for the three different genotypes. Significant differences between least squares means of the different genotypes were calculated using a LSMEANS contrast procedure in SAS as follows;

Additive effect $=[A A-B B] / 2$

Dominance effect $=\mathrm{AB}-[(\mathrm{AA}+\mathrm{BB}) / 2]$ 


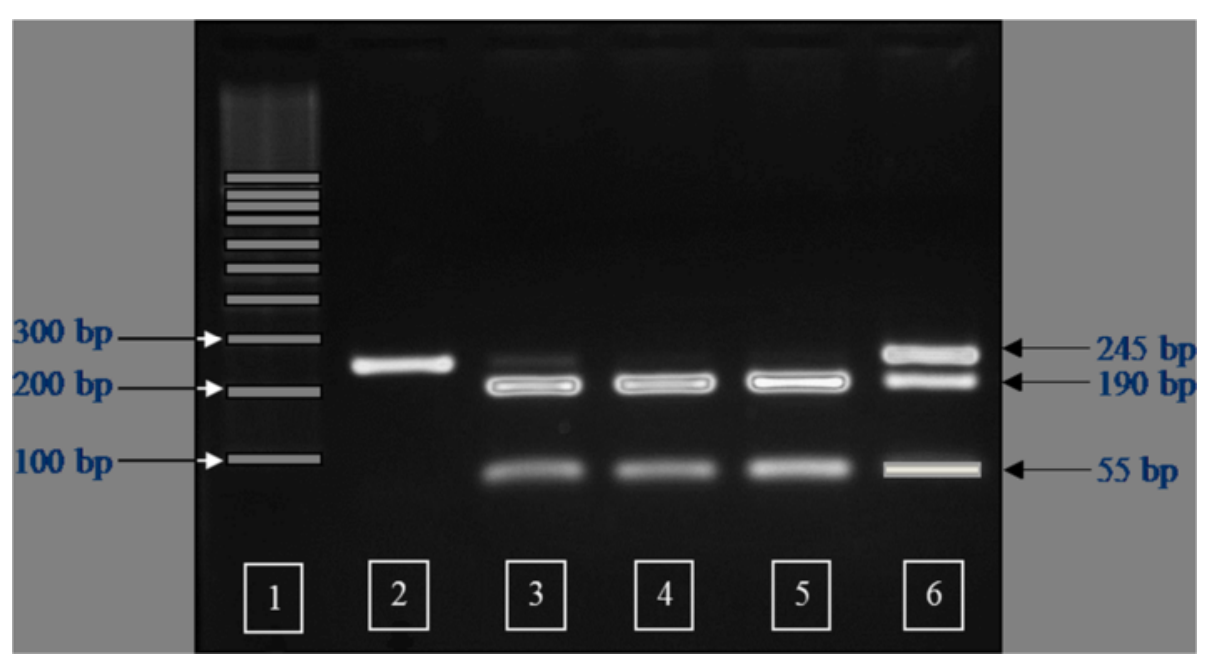

Fig. 1 Agarose gel showing the PCR-RFLP pattern for the IGFBP2 gene amplicons following digestion with Mspl. Lane 1, 100 bp molecular weight standards; Lane 2, AA genotype; Lanes 3-5 BB genotype; Lane 6, AB genotype

The significance was determined as $P<0.05$.

\section{Growth traits}

The statistical analysis model for the MSU Duroc $\times$ Pietrain $F_{2}$ resource population included fixed effects of genotype, sex and parity, and random effects of farrowing group, litter and finishing pen nested within farrowing group, as well as covariates appropriate to each trait. The statistical analysis model for the Duroc pig population included genotype, sex and herd as fixed effects and litter as a random effect.

\section{Carcass and meat quality traits}

The statistical analysis model for the MSU Duroc $x$ Pietrain $F_{2}$ resource population included fixed effects of genotype, sex and slaughter date, random effects of farrowing group and slaughter date nested within farrowing group, and the covariates appropriate to each trait. The statistical analysis model for the Duroc pig population included fixed effects of genotype, sex and slaughter date nested within herd and litter as a random effect.

\section{Results}

\section{PCR-RFLP analysis and nucleotide sequence validation}

The amplification product of the IGFBP 2 intron 2 region was $245 \mathrm{bp}$ in length. Sequencing of this amplicon from multiple individuals showed a $\mathrm{C} / \mathrm{T}$ single nucleotide polymorphism (SNP). The PCR-RFLP method was developed successfully for SNP genotyping using the restriction endonuclease $M s p$ I. Three genotypes were detected and defined as $\mathrm{AA}, \mathrm{AB}$, and $\mathrm{BB}$ (Fig. 1). Observed fragment patterns were: $245 \mathrm{bp}$ for the AA genotype; 245, 190 and $55 \mathrm{bp}$ for the $\mathrm{AB}$ genotype; and 190 and $55 \mathrm{bp}$ for the $\mathrm{BB}$ genotype (Fig. 1). DNA sequencing of samples representing each of the three genotypes confirmed the presence of the MspI recognition site (CCGG; Fig. 2). For the AA genotype, nucleotide sequence at the $M s p$ I recognition site was CTGG instead of CCGG. Thus, the RFLP fragment pattern on agarose gels showed only uncut fragments for the A allele. Nucleotide sequence for animals with the BB genotype revealed an intact recognition site for $M s p$ I (CCGG), and the RFLP pattern on agarose gels showed only the cut fragment pattern. Sequence for animals with the $A B$ genotype indicated the presence of both the $\mathrm{C}$ and $\mathrm{T}$ nucleotides, and the resulting RFLP pattern on agarose gels showed both uncut and cut fragments. The IGFBP2 SNP was submitted to the NCBI dbSNP database (ID\# ss86353533).

\section{Allele and genotype frequency, and genetic linkage analyses}

The genotypic and allelic frequencies of IGFBP2 are shown in Table 1 and were in Hardy-Weinberg equilibrium $\left(\chi^{2}=0.20\right.$ and 1.60; $P=0.90$ and 0.45 for the MSU Duroc $\times$ Pietrain $F_{2}$ resource population and the Duroc pig population, respectively). Genetic linkage analysis using the CRIMAP software version 2.4 [16] estimated the IGFBP2 map position in the MSU Duroc $\times$ Pietrain resource population to be $78.0 \mathrm{cM}$ on pig chromosome 15 (SSC15).

\section{Association of IGFBP2 with growth traits}

Least squares means by IGFBP2 genotype for the growth traits measured in the MSU resource population and the Duroc population are shown in Table 2. Genotype effects $(P<0.05)$ were found for BF10 and LRF at 10, 13, 16 and 19 weeks of age as determined by ultrasound, 

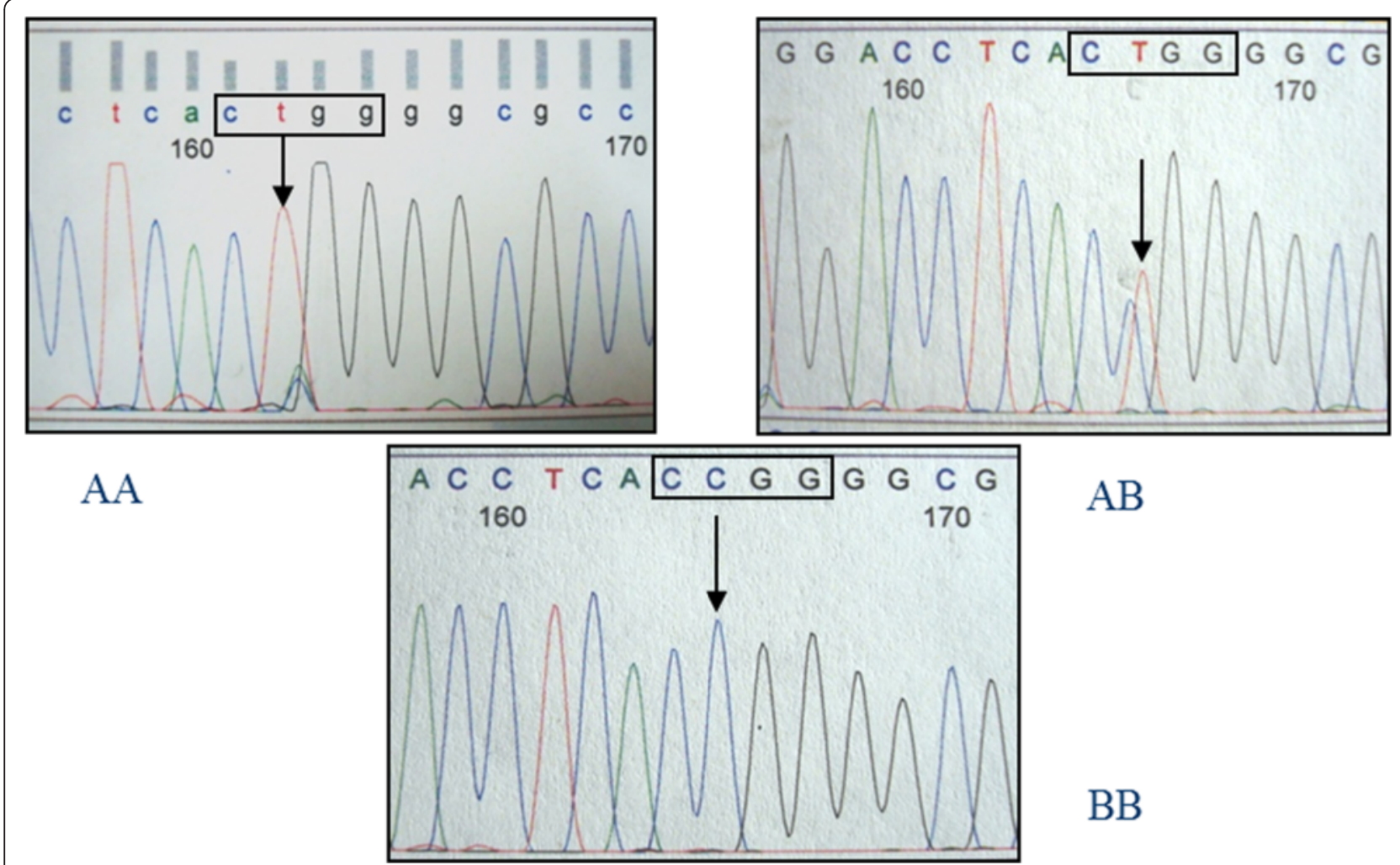

$\mathrm{AB}$

$\mathrm{BB}$

Fig. 2 Nucleotide sequences from reverse direction showing the AA, AB and BB IGFBP2 genotypes (Mspl recognition site =CCGG)

and ADG from 10 to 22 weeks of age, as well as days to $105 \mathrm{~kg}$ for the MSU resource population. For the Duroc pig population, genotype was associated with LMA adjusted to $113 \mathrm{~kg}(P<0.05)$.

As shown in Table 3, the IGFBP2 alleles exhibited additive effects $(P<0.05)$ for ADG and days to $105 \mathrm{~kg}$, whereas a dominance effect $(P<0.05)$ was found for $\mathrm{BF} 10$ at 13 weeks of age in the MSU resource population. For the Duroc pig population, a significant dominance effect was observed for LMA.

\section{Association of IGFBP2 genotypes with carcass traits}

LSMeans by IGFBP2 genotypes for carcass characteristics are presented in Table 4. No significant effect of IGFBP2 genotype was observed for any of the carcass traits $(\mathrm{P}>0.05)$ in the MSU resource population.

Table 1 IGFBP2 genotype frequencies in the MSU Duroc $\times$ Pietrain $F_{2}$ resource population and the Duroc pig population

\begin{tabular}{lllll}
\hline & \multicolumn{2}{l}{ MSU resource population } & \multicolumn{2}{c}{ Duroc population } \\
\hline Genotype & $\mathrm{N}$ & Frequency & $\mathrm{N}$ & Frequency \\
$\mathrm{AA}$ & 14 & 0.0343 & 32 & 0.0982 \\
$\mathrm{AB}$ & 192 & 0.4706 & 156 & 0.4785 \\
BB & 202 & 0.4951 & 138 & 0.4233 \\
Total & 408 & 1 & 326 & 1 \\
\hline
\end{tabular}

\section{Association of IGFBP2 genotypes with meat quality traits}

LSMeans by IGFBP2 genotypes for meat quality traits are presented in Table 5 . Genotype effects $(P<0.05)$ were found in MSU resource population pigs for drip loss, WBS, 24-h pH, pH decline, subjective color score, CIE $L^{*}$ and $b^{*}$ objective color values, and sensory panel juiciness, tenderness, connective tissue and overall tenderness. Moreover, genotype effects $(P<0.05)$ were found in the Duroc population for $45-\mathrm{min} \mathrm{pH}, \mathrm{CIE} \mathrm{L}^{*}$ and color score.

As shown in Table 6, the IGFBP2 alleles exhibited additive effects in the MSU resource population for drip loss, sensory panel tenderness, WBS and sensory panel overall tenderness $(P<0.05)$, and $24-\mathrm{h} \mathrm{pH}$ and sensory panel connective tissue $(P<0.01)$.

\section{Discussion}

Genotyping of pig IGFBP2 using the MspI PCR-RFLP identified in this study allows clear identification of individuals into $\mathrm{AA}, \mathrm{AB}$ or $\mathrm{BB}$ genotypes. Previous studies have reported polymorphisms at the pig IGFBP2 locus $[5,7,17,18]$. Wang et al. [7] identified three pig IGFBP2 polymorphisms. These researchers then conducted an association study with IGFBP2 haplotypes and several body composition and meat quality traits for a population of Lantang $\times$ Landrace pigs $(n=113)$. 
Table 2 Least square means and standard errors for growth traits measured in the MSU pig resource population and the Duroc pig population

\begin{tabular}{|c|c|c|c|c|}
\hline \multirow[t]{2}{*}{ Traits } & \multirow[t]{2}{*}{ Number } & \multicolumn{3}{|l|}{ Genotypes } \\
\hline & & $\mathrm{AA}$ & $A B$ & $\mathrm{BB}$ \\
\hline \multicolumn{5}{|l|}{ MSU resource population } \\
\hline Birth weight, kg & 408 & $1.50 \pm 0.10$ & $1.56 \pm 0.04$ & $1.57 \pm 0.04$ \\
\hline Weaning weight, kg & 408 & $5.31 \pm 0.31$ & $5.59 \pm 0.16$ & $5.51 \pm 0.16$ \\
\hline Body weight 6 wk, kg & 408 & $10.83 \pm 0.70$ & $11.50 \pm 0.48$ & $11.31 \pm 0.48$ \\
\hline Body weight 10 wk, kg & 408 & $24.59 \pm 1.40$ & $25.89 \pm 1.05$ & $25.61 \pm 1.05$ \\
\hline Body weight 13 wk, kg & 408 & $39.88 \pm 1.69$ & $41.31 \pm 1.10$ & $40.56 \pm 1.10$ \\
\hline Body weight 16 wk, kg & 408 & $61.27 \pm 2.04$ & $61.83 \pm 1.10$ & $61.10 \pm 1.09$ \\
\hline Body weight 19 wk, kg & 408 & $80.46 \pm 2.43$ & $80.96 \pm 1.42$ & $79.97 \pm 1.42$ \\
\hline Body weight 22 wk, kg & 408 & $101.95 \pm 2.76$ & $100.51 \pm 1.24$ & $99.96 \pm 1.22$ \\
\hline BF10 $10 \mathrm{wk}, \mathrm{mm}$ & 408 & $7.61 \pm 0.44^{\mathrm{ab}}$ & $8.04 \pm 0.19^{a}$ & $7.66 \pm 0.19^{b}$ \\
\hline BF10 $13 \mathrm{wk}, \mathrm{mm}$ & 408 & $9.15 \pm 0.72^{\mathrm{ab}}$ & $10.00 \pm 0.47^{\mathrm{a}}$ & $9.45 \pm 0.47^{b}$ \\
\hline BF10 $16 \mathrm{wk}, \mathrm{mm}$ & 408 & $12.21 \pm 0.90^{\mathrm{ab}}$ & $12.85 \pm 0.52^{\mathrm{a}}$ & $12.24 \pm 0.52^{b}$ \\
\hline BF10 $19 \mathrm{wk}, \mathrm{mm}$ & 408 & $16.23 \pm 1.27^{\mathrm{ab}}$ & $16.63 \pm 0.74^{\mathrm{a}}$ & $15.62 \pm 0.73^{b}$ \\
\hline BF10 22 wk, mm & 408 & $20.50 \pm 1.53$ & $20.18 \pm 0.80$ & $19.57 \pm 0.79$ \\
\hline LMA $10 \mathrm{wk}, \mathrm{cm}^{2}$ & 408 & $10.08 \pm 0.72$ & $11.04 \pm 0.53$ & $10.99 \pm 0.53$ \\
\hline LMA 13 wk, $\mathrm{cm}^{2}$ & 408 & $15.67 \pm 0.90$ & $16.40 \pm 0.60$ & $16.22 \pm 0.60$ \\
\hline LMA 16 wk, $\mathrm{cm}^{2}$ & 408 & $23.34 \pm 0.99$ & $24.01 \pm 0.53$ & $24.17 \pm 0.52$ \\
\hline LMA 19 wk, $\mathrm{cm}^{2}$ & 408 & $29.60 \pm 1.16$ & $30.92 \pm 0.55$ & $30.86 \pm 0.54$ \\
\hline LMA $22 \mathrm{wk}, \mathrm{cm}^{2}$ & 408 & $35.26 \pm 1.25$ & $36.60 \pm 0.60$ & $36.89 \pm 0.59$ \\
\hline LRF $10 w k, m m$ & 408 & $6.14 \pm 0.29^{\mathrm{ab}}$ & $6.19 \pm 0.12^{a}$ & $5.94 \pm 0.12^{b}$ \\
\hline LRF 13 wk, mm & 408 & $7.15 \pm 0.38^{\mathrm{ab}}$ & $7.28 \pm 0.16^{\mathrm{a}}$ & $6.88 \pm 0.16^{b}$ \\
\hline LRF 16 wk, mm & 408 & $9.54 \pm 0.59^{\mathrm{ab}}$ & $9.67 \pm 0.27^{\mathrm{a}}$ & $9.06 \pm 0.27^{b}$ \\
\hline LRF 19 wk, mm & 408 & $12.41 \pm 0.89^{\mathrm{ab}}$ & $12.16 \pm 0.49^{\mathrm{a}}$ & $11.32 \pm 0.48^{b}$ \\
\hline LRF 22 wk, mm & 408 & $14.36 \pm 1.07$ & $14.79 \pm 0.50$ & $14.22 \pm 0.50$ \\
\hline ADG 10 to 22 wk, g/day & 408 & $939.37 \pm 26.38^{\mathrm{a}}$ & $891.86 \pm 13.22^{b}$ & $888.92 \pm 13.13^{b}$ \\
\hline Days to 105 kg, day & 408 & $148.95 \pm 3.56^{\mathrm{a}}$ & $155.41 \pm 2.14^{\mathrm{b}}$ & $157.63 \pm 2.01^{c}$ \\
\hline \multicolumn{5}{|l|}{ Duroc pig population } \\
\hline BF10, mm & 277 & $13.89 \pm 0.47$ & $13.47 \pm 0.25$ & $13.53 \pm 0.27$ \\
\hline LMA, $\mathrm{cm}^{2}$ & 277 & $47.04 \pm 0.75^{\mathrm{ab}}$ & $47.75 \pm 0.40^{\mathrm{a}}$ & $46.40 \pm 0.43^{b}$ \\
\hline Days to $105 \mathrm{~kg}$, day & 277 & $165.57 \pm 2.20$ & $167.02 \pm 1.14$ & $165.84 \pm 1.23$ \\
\hline
\end{tabular}

$\mathrm{a}, \mathrm{b}, \mathrm{c}$ Least square means within the same row with different superscripts differ $(P<0.05)$

The traits evaluated by Wang et al. [7] differed from those evaluated in the present study so it is not possible to directly compare results. In addition, the pig breeds and specific IGFBP2 polymorphisms evaluated between the two studies differed.

Genetic linkage analysis using the CRIMAP software version 2.4 [16] estimated the IGFBP2 map position in the MSU resource population to be $78.0 \mathrm{cM}$ on SSC15. Microsatellite markers linked to IGFBP2 in the MSU resource population were consistent with microsatellites found to be linked to IGFBP2 by other groups reporting either radiation hybrid mapping [7] or linkage mapping [17] of IGFBP2 to SSC15. The gene PRKAG3 (protein kinase, AMP-activated, gamma 3 non-catalytic subunit), which has been shown to be associated with pork quality traits including glycolytic potential, ultimate $\mathrm{pH}$ and color $[19,20]$, is also located in this region of SSC15 [9]. However, it is unclear how closely linked IGFBP2 and PRKAG3 are because the two genes have not been located on a common map. It is not currently possible to confirm the physical map position for IGFBP2 in the pig genome reference sequence (Sus scrofa ver 10.2) because this gene is currently aligned to an unassembled contig (Ensembl Scaffold JH118558.1: 46,034-68,435), and thus it remains unmapped in the most recent genome assembly. Several significant QTL affecting meat 
Table 3 Genetic effects of IGFBP2 on growth traits for the MSU Duroc $\times$ Pietrain $F_{2}$ resource population and the Duroc pig population

\begin{tabular}{lll}
\hline Traits & Additive effect & Dominance effect \\
\hline MSU resource population & & \\
BF10 13 wk, $\mathrm{mm}$ & $-0.15 \pm 0.29$ & $0.69 \pm 0.33^{*}$ \\
ADG 10 to $22 \mathrm{wk}, \mathrm{g} /$ day & $25.84 \pm 12.03^{*}$ & $-23.04 \pm 11.19$ \\
Days to $105 \mathrm{~kg}$, day & $-4.34 \pm 1.51^{*}$ & $2.12 \pm 1.75$ \\
Duroc pig population & & \\
LMA $\mathrm{cm}^{2}$ & $-0.32 \pm 0.41$ & $1.03 \pm 0.52^{*}$ \\
\hline
\end{tabular}

Significance was determined as $P<0.05(*)$, additive effects represent the effect of allele $A$

quality traits, including color and tenderness, have been identified in the MSU resource population within the SSC15 region containing the IGFBP2 gene [7, 10, 14]. Wang et al. [7] found IGFBP2 haplotypes associated with meat color and marbling in a Lantang $\times$ Landrace pig population. Therefore, IGFBP2 maps to a chromosome region containing significant QTL that affect economically important traits and could be a potential candidate gene for further study.

\section{Association of IGFBP2 gene with growth traits}

Average daily gain (ADG) is one of the most economically important traits and it is used in pig selection indexes. This study found pigs in the MSU resource population with the AA genotype had the fastest weight gain when compared to pigs with the $\mathrm{AB}$ or $\mathrm{BB}$ genotype. The results were consistent with a report in beef cattle by Pagan [6] who considered IGFBP2 as a candidate gene and found an association of IGFBP2 with days on feed. Moreover, a favorable additive effect was detected for ADG $(P<0.05)$ such that the additive effect was approximately $26 \mathrm{~g} /$ day per copy of the A allele. Backfat deposition traits (BF10 and LRF), which are important for most pig producers and also pork consumers, were also found to be associated with IGFBP2 genotype in the MSU resource population when measured at 10, 13, 16 and 19 weeks of age. Pigs with the BB genotype had lower backfat thickness than pigs with the AB genotype. While Wang et al. [7] did not evaluate subcutaneous backfat thickness, they did find an association of IGFBP2 with leaf fat weight. In addition, Li et al. [5] reported that IGFBP2 in chicken was associated with multiple traits including abdominal fat. Thus, IGFBP2 might indirectly affect adipocyte differentiation by controlling IGFs in fat tissue [21].

The end weight goals were different for the MSU resource population and the Duroc population pigs. However, while IGFBP2 genotype was significantly associated with BF10 and LRF from 10 to 19 weeks of age for the MSU resource population pigs, at 22 weeks of age, BF10 and LRF were not significantly associated with IGFBP2 genotype. Similarly, off test BF10 was not associated with IGFBP2 genotype for the Duroc pig population although $\mathrm{AB}$ genotype pigs exhibited larger off test LMA than BB genotype pigs. Thus, differences between IGFBP2 genotype classes for backfat thickness at

Table 4 Least square means and standard errors for carcass characteristics of the MSU Duroc $\times$ Pietrain $F_{2}$ resource population separated by IGFBP2 genotypes

\begin{tabular}{|c|c|c|c|c|}
\hline \multirow[t]{2}{*}{ Traits } & \multirow[t]{2}{*}{ Number } & \multicolumn{3}{|l|}{ Genotypes } \\
\hline & & $\mathrm{AA}$ & $A B$ & $\mathrm{BB}$ \\
\hline Off-farm body weight, kg & 408 & $114.16 \pm 2.31$ & $112.78 \pm 1.06$ & $113.09 \pm 1.06$ \\
\hline Hot carcass weight, $\mathrm{kg}$ & 408 & $82.56 \pm 1.78$ & $82.25 \pm 0.79$ & $82.58 \pm 0.78$ \\
\hline Dressing percent & 408 & $72.30 \pm 0.49$ & $72.94 \pm 0.22$ & $72.96 \pm 0.22$ \\
\hline Carcass length, $\mathrm{cm}$ & 408 & $78.32 \pm 0.58$ & $78.54 \pm 0.22$ & $78.62 \pm 0.22$ \\
\hline First-rib backfat, mm & 372 & $40.35 \pm 1.84$ & $41.50 \pm 0.99$ & $41.03 \pm 0.97$ \\
\hline $10^{\text {th }}$-rib backfat, $\mathrm{mm}$ & 433 & $24.08 \pm 1.53$ & $24.33 \pm 0.65$ & $23.94 \pm 0.63$ \\
\hline Last-rib backfat, mm & 408 & $28.93 \pm 1.58$ & $28.75 \pm 0.88$ & $28.76 \pm 0.87$ \\
\hline Last-lumbar vertebra backfat, mm & 408 & $22.30 \pm 1.58$ & $22.52 \pm 0.71$ & $22.53 \pm 0.71$ \\
\hline LMA at $10^{\text {th }}$ rib, $\mathrm{cm}^{2}$ & 404 & $39.33 \pm 1.06$ & $40.37 \pm 0.34$ & $40.73 \pm 0.32$ \\
\hline Number of ribs in carcass & 298 & $15.08 \pm 0.17$ & $14.84 \pm 0.06$ & $14.87 \pm 0.05$ \\
\hline Ham weight, kg & 408 & $9.93 \pm 0.13$ & $9.75 \pm 0.06$ & $9.81 \pm 0.06$ \\
\hline Loin weight, kg & 408 & $8.27 \pm 0.17$ & $8.24 \pm 0.09$ & $8.31 \pm 0.09$ \\
\hline Boston shoulder weight, $\mathrm{kg}$ & 408 & $3.78 \pm 0.12$ & $3.80 \pm 0.09$ & $3.81 \pm 0.09$ \\
\hline Picnic shoulder weight, kg & 408 & $3.81 \pm 0.12$ & $3.87 \pm 0.10$ & $3.89 \pm 0.10$ \\
\hline Belly weight, kg & 408 & $5.09 \pm 0.10$ & $5.05 \pm 0.05$ & $5.04 \pm 0.05$ \\
\hline Spareribs weight, kg & 408 & $1.49 \pm 0.04$ & $1.50 \pm 0.02$ & $1.50 \pm 0.02$ \\
\hline
\end{tabular}


Table 5 Least square means and standard errors for meat quality traits of MSU Duroc $\times$ Pietrain $F_{2}$ resource population and Duroc population pigs separated by IGFBP2 genotypes

\begin{tabular}{|c|c|c|c|c|}
\hline \multirow[t]{2}{*}{ Traits } & \multirow[t]{2}{*}{ Number } & \multicolumn{3}{|l|}{ Genotypes } \\
\hline & & $\overline{\mathrm{AA}}$ & $A B$ & $\mathrm{BB}$ \\
\hline \multicolumn{5}{|l|}{ MSU resource population } \\
\hline Drip loss, $\%$ & 405 & $2.13 \pm 0.31^{\mathrm{a}}$ & $1.79 \pm 0.14^{b}$ & $1.44 \pm 0.14^{b}$ \\
\hline WBS, kg & 406 & $3.40 \pm 0.18^{\mathrm{a}}$ & $3.24 \pm 0.09^{\mathrm{a}}$ & $3.03 \pm 0.09^{b}$ \\
\hline 45-min $\mathrm{pH}$ & 405 & $6.37 \pm 0.06$ & $6.35 \pm 0.02$ & $6.36 \pm 0.02$ \\
\hline 45 -min temp, ${ }^{\circ} \mathrm{C}$ & 408 & $39.33 \pm 0.49$ & $39.29 \pm 0.40$ & $39.17 \pm 0.40$ \\
\hline 24-h pH & 398 & $5.48 \pm 0.03^{\mathrm{a}}$ & $5.51 \pm 0.01^{b}$ & $5.60 \pm 0.01^{c}$ \\
\hline 24-h temp, ${ }^{\circ} \mathrm{C}$ & 407 & $2.71 \pm 0.24$ & $2.77 \pm 0.19$ & $2.79 \pm 0.19$ \\
\hline $\mathrm{pH}$ decline & 395 & $0.88 \pm 0.06^{\mathrm{ab}}$ & $0.83 \pm 0.02^{\mathrm{a}}$ & $0.77 \pm 0.02^{b}$ \\
\hline Firmness score & 408 & $3.02 \pm 0.22$ & $2.86 \pm 0.09$ & $2.77 \pm 0.09$ \\
\hline Marbling score & 408 & $2.87 \pm 0.22$ & $2.76 \pm 0.10$ & $2.76 \pm 0.09$ \\
\hline Color score & 408 & $3.06 \pm 0.24^{\mathrm{ab}}$ & $3.05 \pm 0.07^{\mathrm{a}}$ & $3.28 \pm 0.06^{b}$ \\
\hline CIE $L^{*}$ value & 381 & $53.86 \pm 0.61^{\mathrm{ab}}$ & $54.09 \pm 0.18^{\mathrm{a}}$ & $53.37 \pm 0.17^{b}$ \\
\hline CIE $a^{*}$ value & 381 & $16.92 \pm 0.26$ & $16.96 \pm 0.07$ & $17.14 \pm 0.07$ \\
\hline CIE b* value & 381 & $9.00 \pm 0.20^{\mathrm{ab}}$ & $9.24 \pm 0.06^{\mathrm{a}}$ & $9.09 \pm 0.06^{\mathrm{b}}$ \\
\hline Juiciness score & 402 & $5.09 \pm 0.16^{\mathrm{ab}}$ & $5.20 \pm 0.04^{\mathrm{a}}$ & $5.34 \pm 0.04^{b}$ \\
\hline Tenderness score & 406 & $5.33 \pm 0.16^{\mathrm{a}}$ & $5.48 \pm 0.05^{\mathrm{a}}$ & $5.70 \pm 0.04^{b}$ \\
\hline Connective tissue score & 406 & $6.16 \pm 0.10^{\mathrm{a}}$ & $6.36 \pm 0.03^{\mathrm{ab}}$ & $6.44 \pm 0.03^{b}$ \\
\hline Off-flavor score & 406 & $1.26 \pm 0.06$ & $1.16 \pm 0.02$ & $1.17 \pm 0.02$ \\
\hline Overall Tenderness score & 406 & $5.44 \pm 0.15^{\mathrm{a}}$ & $5.55 \pm 0.04^{\mathrm{a}}$ & $5.77 \pm 0.04^{b}$ \\
\hline \multicolumn{5}{|l|}{ Duroc pig population } \\
\hline 45-min $\mathrm{pH}$ & 226 & $6.41 \pm 0.04^{\mathrm{ab}}$ & $6.44 \pm 0.02^{\mathrm{a}}$ & $6.39 \pm 0.02^{b}$ \\
\hline 24-h pH & 307 & $5.84 \pm 0.03$ & $5.86 \pm 0.02$ & $5.85 \pm 0.02$ \\
\hline $\mathrm{pH}$ decline & 223 & $0.59 \pm 0.05$ & $0.60 \pm 0.03$ & $0.55 \pm 0.03$ \\
\hline $\mathrm{ClE} \mathrm{L}^{*}$ & 312 & $50.94 \pm 0.42^{\mathrm{ab}}$ & $50.80 \pm 0.22^{\mathrm{a}}$ & $51.48 \pm 0.22^{\mathrm{b}}$ \\
\hline Color score & 325 & $2.95 \pm 0.11^{\mathrm{ab}}$ & $2.99 \pm 0.06^{\mathrm{a}}$ & $2.87 \pm 0.06^{\mathrm{b}}$ \\
\hline Marbling score & 326 & $2.38 \pm 0.20$ & $2.23 \pm 0.10$ & $2.30 \pm 0.10$ \\
\hline
\end{tabular}

$\mathrm{a}, \mathrm{b}, \mathrm{c}$ Least square means within the same row with different superscripts differ $(P<0.05)$

Table 6 Genetic effects of IGFBP2 on meat quality traits in the MSU Duroc $\times$ Pietrain $F_{2}$ resource population

\begin{tabular}{lll}
\hline Traits & Additive effect & Dominance effect \\
\hline Drip loss, \% & $0.35 \pm 0.15^{*}$ & $0.003 \pm 0.17$ \\
24-h pH & $-0.06 \pm 0.02^{* *}$ & $-0.03 \pm 0.02$ \\
Tenderness & $-0.18 \pm 0.08^{*}$ & $-0.04 \pm 0.09$ \\
WBS, kg & $0.18 \pm 0.09^{*}$ & $0.01 \pm 0.10$ \\
Connective tissue & $-0.14 \pm 0.05^{* *}$ & $0.07 \pm 0.06$ \\
Overall tenderness & $-0.16 \pm 0.08^{*}$ & $-0.05 \pm 0.08$ \\
\hline
\end{tabular}

Significance was determined as $P<0.05(*)$ and $P<0.01\left({ }^{*}\right)$, respectively, additive effects represent the effect of allele $A$ younger ages may not be related with backfat thickness at market age. However, if IGFBP2 genotype associations are confirmed, this information could help pig producers through optimization of feeding and management practices.

\section{Association of IGFBP2 genotypes with carcass traits}

No significant associations were observed between IGFBP2 genotypes and carcass traits in the MSU Duroc $\times$ Pietrain resource population. In contrast, Wang et al. [7] observed that IGFBP2 haplotypes of Lantang $\times$ Landrace pigs were associated with fore-body weight, rear-body weight, bone weight of the rear-body, forelimb weight, rearlimb weight, leaf fat weight, stomach weight, number of ribs and body length. These investigators indicated that their experimental population was too small $(n=113)$ to verify their results. Many of the traits 
evaluated in the present study differed from those evaluated by Wang et al. [7] and those traits that were in common were not confirmed by our study. In addition, the pig breeds and specific IGFBP2 polymorphisms evaluated between the two studies differed.

\section{Association of IGFBP2 genotypes with meat quality traits} Pork quality is greatly affected by the ultimate $\mathrm{pH}$ of the meat reached during the first $24 \mathrm{~h}$ after exsanguination, as well as the rate of $\mathrm{pH}$ decline. This is due to the anaerobic metabolic decomposition of the glycogen reserves in the muscles that results in the production of lactic acid and a subsequent decline in $\mathrm{pH}$. This process can lead to denaturation of muscle proteins if the decline in $\mathrm{pH}$ is too great or if the carcass temperature is too high at even moderately low $\mathrm{pH}$ levels, which in turn may result in meat with poor water holding capacity, and in extreme cases, pale, soft and exudative (PSE) meat [22]. Normally, the 24-h pH of muscle drops to between 5.5 and 5.8. If the $\mathrm{pH}$ declines very rapidly or very slowly, or if the ultimate $\mathrm{pH}$ is very high (above 6.1-6.2) or very low $(<5.4)$, carcass quality characteristics, including water-holding capacity and color, will be significantly affected, potentially leading to PSE or dark, firm and dry (DFD) pork [23]. Therefore, 24-h $\mathrm{pH}$ along with drip loss and color are important indicators for optimizing meat quality. Results of this study indicated a significant effect of IGFBP2 genotype on initial LM pH (45-min $\mathrm{pH})$ in the Duroc pig population such that the BB genotype pigs had an unfavorable 45min $\mathrm{pH}$. However, 45-min $\mathrm{pH}$ was not significantly associated with IGFBP2 genotype in the MSU resource population. Furthermore, ultimate $\mathrm{pH}(24-\mathrm{h} \mathrm{pH})$ and $\mathrm{pH}$ decline were significantly associated with IGFBP2 genotype in the MSU resource population. For this study, LM 24-h pH ranged from 5.46 to 5.86, which was consistent with previous studies (ranging from 5.34 to 5.80 ; [24-26]). The 24-h pH of BB genotype pigs in the MSU resource population $(5.60 \pm 0.01)$ was more favorable $(P<0.05)$ than 24 -h $\mathrm{pH}$ for pigs with either the AA genotype $(5.48 \pm 0.03)$ or the $\mathrm{AB}$ genotype (5.51 \pm 0.01 ). In addition, $\mathrm{pH}$ decline showed similar results in that pigs with the $\mathrm{BB}$ genotype had lower $(P<0.05) \mathrm{pH}$ decline $(0.77 \pm 0.02)$ than those from pigs with the $A B$ genotype $(0.83 \pm 0.02)$.

Drip loss was also found to be associated with IGFBP2 genotypes. High drip loss conditions are caused by denaturation of myosin, whereas the fraction of myosin denatured increases with rapid $\mathrm{pH}$ decline and low 24-h $\mathrm{pH}$ [27]. Previous studies have shown that 24-h pH has a significant negative correlation with drip loss (range -0.49 to $-0.62 ;[25,28,29])$. Drip loss is the parameter that indicates the ability of pork to retain moisture (water-holding capacity; WHC) and is an essential quality parameter for both pork producers and consumers. For pork producers, low WHC (high drip loss) implies increased economic losses, and consequently, are interested in optimizing this parameter [30]. The WHC of fresh pork is also known to influence its technological quality, such as processing yield. For pork consumers, low WHC (high drip loss) has an unfavorable impact on the appearance of fresh meat cuts during retail and may influence the sensory quality of the pork $[31,32]$. Several factors have been shown to affect the WHC of pork; genotype, particularly the $\mathrm{RN}^{-}$gene (i.e., PRKAG3) [33], pre-slaughter stress and stunning method [34], as well as the cooling regime used on the carcass [30]. Results from the present study found pigs with the $\mathrm{AB}(1.79 \pm 0.14 \%)$ and $\mathrm{BB}(1.44 \pm 0.14 \%)$ genotypes to have more desirable $(P<0.05)$ drip loss than pigs with the AA $(2.13 \pm 0.31 \%)$ genotype, consistent with the results for 24-h $\mathrm{pH}$ and $\mathrm{pH}$ decline, indicating that pigs with the $\mathrm{BB}$ genotype had more favorable phenotypes.

Consumer perceptions of fresh meat products are affected, at least in part, by color and firmness such that darker meat color and more firm products are more desirable. In addition, during the pork chain quality audit, packers reported a $10 \%$ incidence of PSE pork and a $4 \%$ incidence of DFD pork [35]. The association between PSE and DFD quality defects with their respective colors has led the industry to assign visual color scores to carcasses [36], and the use of instrumental color evaluation [37] is of significant interest to the industry because of its speed, consistency of measures, and potential for use as the basis for sorting. Therefore, color is an important economic trait for pork. Various studies have shown an effect of $\mathrm{pH}$ on color. Martin et al. [38] evaluated 3,114 pigs from three commercial plants and found 24-h pH explained 40 to $53 \%$ of the variation in fresh pork color. Dransfield et al. [39] evaluated objective color on a population with a wide range of 24-h pH (5.6 to 6.9) and found that $24-\mathrm{h} \mathrm{pH}$ explained $53 \%$ of the variation in CIE L* values. DeVol et al. [40] found significant correlations between loin $\mathrm{pH}$ and subjective color $(r=0.62)$. Bidner et al. [41] also reported that loin 24-h $\mathrm{pH}$ was significantly correlated with CIE L*, a* and b* objective color values ( $r=-0.68,-0.23$ and -0.47 , respectively). Results of the present study indicated that in the MSU Duroc $x$ Pietrain $\mathrm{F}_{2}$ resource population, pigs with the BB genotype had favorable $(P<0.05)$ subjective color scores $(3.28 \pm 0.06)$, and objective color values for CIE $L^{*}$ $(53.37 \pm 0.17)$ and $b^{*}(9.09 \pm 0.06)$. In contrast, for the Duroc pig population, pigs with BB genotype had unfavorable 45 - $\mathrm{min} \mathrm{pH}(6.39 \pm 0.02)$, CIE L* $(51.48 \pm 0.22)$ and subjective color score $(2.87 \pm 0.06)$. The MSU resource population results agreed with Wang et al. [7] 
who found different IGFBP2 haplotypes to have significant effects on meat color in Lantang $\times$ Landrace pork. Furthermore, the MSU resource population results also tended to follow the results for 24-h $\mathrm{pH}$, because pork color is influenced by residual enzyme activity that will be higher with higher 24-h pH resulting in de-oxidation of oxymyoglobin and consequently darker meat color [32].

Another important trait affecting pork quality is tenderness. Results of this study revealed a significant association of IGFBP2 genotypes with both a mechanical measure of tenderness (WBS) and a sensory panel assessment of tenderness. Pigs with the IGFBP2 BB genotype had the lowest $(P<0.05)$ WBS $(3.03 \pm 0.09 \mathrm{~kg})$ as compared to pigs with $\mathrm{AA}(3.40 \pm 0.18 \mathrm{~kg})$ or $\mathrm{AB}$ $(3.24 \pm 0.09 \mathrm{~kg})$ genotypes indicating that $\mathrm{BB}$ pigs had more tender loin muscles. Pigs with the BB genotype also had the most favorable $(P<0.05)$ sensory panel tenderness $(5.70 \pm 0.04)$ and overall tenderness $(5.77 \pm$ $0.04)$ values. In addition, sensory panel values for juiciness $(5.34 \pm 0.04)$ and connective tissue $(6.44 \pm 0.03)$ were more desirable $(P<0.05)$ for pigs with the $\mathrm{BB}$ genotype. These observations appear to be consistent with the observations for other meat quality traits in this study. Howard and Lawrie [42] found that the rate of $\mathrm{pH}$ decline postmortem was inversely related to meat tenderness. Similarly, Marsh et al. [43] indicated that increased tenderness is observed when $\mathrm{pH}$ declines slowly. Thus, the more favorable $24-\mathrm{h} \mathrm{pH}$ and $\mathrm{pH}$ decline phenotypes for IGFBP2 BB genotype pigs appear to be consistent with the favorable drip loss, color, WBS and eating quality traits observed in MSU Duroc $\times$ Pietrain $F_{2}$ resource population pigs.

\section{Conclusions}

The IGFBP2 alleles in MSU Duroc $\times$ Pietrain $\mathrm{F}_{2}$ resource population pigs exhibited additive genetic effects for ADG, whereas a dominance effect was found for BF10 at 13 weeks of age. Pigs with the AA genotype had faster weight gain from 10 to 22 weeks of age than pigs with the $\mathrm{AB}$ or $\mathrm{BB}$ genotypes. Moreover, pigs with the $\mathrm{BB}$ genotype had less backfat thickness than pigs with the $A B$ genotype as determined by ultrasound from 10 to 19 weeks of age. Therefore, pigs with the BB genotype appear to have more desirable backfat thickness, albeit with less desirable rate of weight gain. The effects on growth rate and backfat thickness observed in the resource population were not confirmed in the Duroc population. However, the end weight goals were different for the two populations. The off-test backfat measures were not significantly associated with IGFBP2 genotype in either population. Thus, differences between IGFBP2 genotype classes for backfat thickness at younger ages may not be related with backfat thickness at market age. However, if IGFBP2 genotype associations are confirmed, this information could help pig producers through optimization of feeding and management practices.

Significant associations of IGFBP2 genotype were found in the MSU Duroc $\times$ Pietrain $F_{2}$ resource population for 24-h $\mathrm{pH}, \mathrm{pH}$ decline, drip loss, subjective color score, CIE L* and $b^{*}$ objective color values, WBS, and sensory panel juiciness, tenderness, overall tenderness and connective tissue. Furthermore, associations were found in the Duroc pig population for CIE $\mathrm{L}^{*}$ and color score. Pigs with the BB genotype were found to have more desirable phenotypes for significant traits in the MSU resource population. However, in the Duroc pig population, pigs with the $\mathrm{BB}$ genotype had unfavorable phenotypes for significant color traits. The IGFBP2 alleles exhibited additive effects for drip loss, 24-h $\mathrm{pH}$, WBS, and sensory panel tenderness, overall tenderness and connective tissue in the MSU resource population. The results indicate IGFBP2 as a potential candidate gene useful for growth rate, backfat thickness, loin muscle area and some pork quality traits in pigs, with the allele considered to be more favorable differing depending on the selection goals for the population.

\section{Abbreviations \\ ADG: Average daily gain; BF10: $10^{\text {th }}$ rib backfat thickness; DFD: Dark, firm, and dry; $F_{0}$ : Grandparents; $F_{1}$ : First filial generation; $F_{2}$ : Second filial generation; HWE: Hardy-Weinberg equilibrium; IGFBP2: Insulin-like growth factor binding protein 2; LM: Longissimus muscle; LMA: Longissimus muscle area; LRF: Last rib backfat thickness; MSU: Michigan State University; NSIF: National Swine Improvement Federation; NSR: National Swine Registry; PCR: Polymerase chain reaction; PSE: Pale, soft and exudative; QTL: Quantitative trait locus; RFLP: Restriction fragment length polymorphism; SNP: Single nucleotide polymorphism; SSC: SUs scrofa (porcine) chromosome; USA: United States of America; WBS: Warner-Bratzler shear force; WHC: Water holding capacity.}

\section{Competing interests}

The authors declare that they have no competing interests.

\section{Authors' contributions}

SP, IC and NER conducted the laboratory work. SP and IC performed the statistical analyses. ROB, CWE, IC and NER collected and provided phenotypic data and DNA. CWE conceived of and designed the study. SP, CWE and ST drafted the manuscript. All authors assisted with data analysis and interpretation, and edited the manuscript. All authors read and approved the final manuscript.

\section{Acknowledgements}

The authors would like to thank Rilington VD, Edwards DB and other staff in the Molecular Genetics Laboratory, Department of Animal Science, Michigan State University, East Lansing, MI, USA for providing technical assistance and phenotypic data. This research was financed by Thailand Research Fund (TRF) under the Royal Golden Jubilee Ph.D. Program.

\section{Author details}

'Department of Animal Science, Kasetsart University, Bangkok 10900, Thailand. ${ }^{2}$ Department of Animal Science, Michigan State University, East Lansing, MI 48824, USA. ${ }^{3}$ Animal Parasitic Diseases Laboratory, ARS, USDA, Beltsville, MD 20705, USA.

Received: 16 June 2015 Accepted: 17 August 2015

Published online: 03 September 2015 


\section{References}

1. Van Wijk HJ, Arts DJG, Matthews JO, Webster M, Ducro BJ, Knol EF. Genetic parameters for carcass composition and pork quality estimated in a commercial production chain. J Anim Sci. 2005;83:324-33.

2. Blanchard PJ, Warkup CC, Ellis M, Willis MB, Avery P. The influence of the proportion of Duroc genes on growth, carcass and pork eating quality characteristics. Anim Sci. 1999;68:495-501.

3. Edwards DB, Bates RO, Osburn WN. Evaluation of Duroc- vs. Pietrain-sired pigs for growth and composition. J Anim Sci. 2006;84:266-75.

4. Dekkers JCM, Hospital F. The use of molecular genetics in the improvement of agricultural populations. Nature. 2002;3:21-31.

5. $\quad \mathrm{Li} \mathrm{ZH}$, Li H, Zhang H, Wang SZ, Wang QG, Wang YX. Identification of a single nucleotide polymorphism of the insulin-like growth factor binding protein 2 gene and its association with growth and body composition traits in the chicken. J Anim Sci. 2006;84:2902-6.

6. Pagan MJ. Evaluation of serum insulin-like growth factor binding proteins and the insulin-like growth factor binding protein-2 locus for potential associations with growth, carcass merit and meat quality in beef cattle, PhD Diss. East Lansing, USA: Michigan State University; 2002.

7. Wang W, Meng Q, Hu X, Fei J, Feng J, Liu W, et al. Chromosome location and association of haplotypes of insulin-like growth factor binding protein-2 with production performance in swine. Biochem Genet. 2008:46:381-91.

8. Malek M, Dekkers JCM, Lee HK, Baas TJ, Prusa K, Huff-Lonergan E, et al A molecular genome scan analysis to identify chromosomal regions influencing economic traits in the pig. II. Meat and muscle composition. Mamm Genome. 2001;12:637-45.

9. Rohrer GA, Thallman RM, Shackelford S, Wheeler T, Koohmaraie M. A genome scan for loci affecting pork quality in a Duroc-Landrace $F_{2}$ population. Anim Genet. 2006:37:17-27.

10. Edwards DB, Ernst CW, Raney NE, Doumit ME, Hoge MD, Bates RO. Quantitative trait loci mapping in an F2 Duroc $\times$ Pietrain resource population: II. Carcass and meat quality traits. J Anim Sci. 2008:86:254-66.

11. Knott SA, Marklund L, Haley CS, Andersson K, Davies W, Ellegren H, et al. Multiple marker mapping of quantitative trait loci in a cross between outbred wild boar and large white pigs. Genetics. 1998:149:1069-80.

12. National Research Council (NRC). Nutrient requirements of swine. 10th ed. Washington, D.C, USA: National Academy Press; 1998.

13. Edwards DB, Ernst CW, Tempelman RJ, Rosa GJM, Raney NE, Hoge MD, et al. Quantitative trait loci mapping in an F2 Duroc $\times$ Pietrain resource population: I. Growth traits. J Anim Sci. 2008;86:241-53.

14. Choi I, Bates RO, Raney NE, Steibel JP, Ernst CW. Evaluation of QTL for carcass merit and meat quality traits in a US commercial Duroc population. Meat Sci. 2012;92:132-8.

15. National Swine Improvement Federation (NSIF). Guidelines for uniform swine improvement programs. http://www.nsif.com/guidel/guidelines.htm (2006). Accessed 1 May 2010.

16. Green P, Falls K, Crooks S. Documentation for CRIMAP, version 2.4. St. Louis, MO, USA: Washington Univ. School of Medicine; 1990.

17. Mote BE, Rothschild MF. SNP detection and linkage mapping for pig genes involved in growth. Anim Genet. 2006:37:293-307.

18. Sironen Al, Uimari P, Serenius T, Mote B, Rothschild M, Vilkki J. Effect of polymorphisms in candidate genes on reproduction traits in Finnish pig populations. J Anim Sci. 2010;88:821-7.

19. Ciobanu DC, Bastiaansen J, Malek M, Helm J, Woollard J, Plastow G. Evidence for new alleles in the protein kinase adenosine monophosphateactivated $\gamma 3$-subunit gene associated with low glycogen content in pig skeletal muscle and improved meat quality. Genetics. 2001;159:1151-62.

20. Milan D, Jeon JT, Looft C, Amarger V, Robic A, Thelander M. A mutation in PRKAG3 associated with excess glycogen content in pig skeletal muscle. Science. 2000;288:1248-51.

21. Richardson RL, Hausman GJ, Wright JT. Growth factor regulation of insulin-like growth factor binding protein (IGFBP) and pre-adipocyte differentiation in porcinestromal-vascular cell cultures. Growth Dev Aging. 1998;62:3-12.

22. Anderson JR. Optical measurements of $\mathrm{pH}$ in meat. Meat Sci. 1999;53:135-41.

23. Bendall JR, Swatland HJ. A review of the relationships of $\mathrm{pH}$ with physical aspect of pork quality. Meat Sci. 1988;24:85-99.

24. D'Souza DN, Mullan BP. The effect of genotype, sex and management strategy on the eating quality of pork. Meat Sci. 2002;60:95-101.
25. Lundstrom K, Anderson A, Hansson I. Effect of the RN gene on technological and sensory meat quality in crossbred pigs with Hampshire as a terminal sire. Meat Sci. 1996;42:145-53.

26. Schaffer A, Rosenvold K, Purslow PP, Andersen HJ, Henckel P. Physiological and structural events post mortem of importance for drip loss in pork. Meat Sci. 2002:61:355-66.

27. Offer G. Modeling of the formation of pale, soft and exudative meat: effect of chilling regime and rate and extent of glycolysis. Meat Sci. 1991;30:157-84

28. Bidner BS, Ellis M, Brewer MS, Campion D, Wilson ER, McKeith FK. Effect of ultimate $\mathrm{pH}$ on the quality characteristics of pork. J Muscle Foods. 2004;15:139-54.

29. Long VP, Tarrent PV. The effect of pre-slaughter showering and postslaughter rapid chilling on meat quality in intact pork sides. Meat Sci. 1990;27:181-95.

30. Maribo H, Olsen EV, Barton-Gade P, Moller AJ, Karlsson A. Effect of early post-mortem cooling on temperature, $\mathrm{pH}$ fall and meat quality in pigs. Meat Sci. 1998;50:115-29.

31. Kauffman RG, Wachholz D, Henderson D, Lochner JV. Shrinkage of PSE, normal and DFD hams during transit and processing. J Anim Sci. 1978:46:1236-40.

32. Lawrie RA, Ledward DA. Lawrie's meat science. 7th ed. Cambridge, UK: Woodhead Publishing; 2006.

33. Hamilton DN, Ellis M, Miller KD, McKeith FK, Parrett DF. The effect of the halothane and Rendement Napole genes on carcass and meat quality characteristics of pigs. J Anim Sci. 2000;78:2862-7.

34. Stoier S, Aaslyng MD, Olsen EV, Henckel P. The effect of stress during lairage and stunning on muscle metabolism and drip loss in Danish pork. Meat Sci. 2000;59:127-31.

35. Cannon JE, Morgan JB, McKeith FK, Smith GC, Sonka S, Heavner J, et al. Pork chain quality audit survey: quantification of pork quality characteristics. J Muscle Foods. 1996;7:29-44.

36. Brewer MS, Zhu LG, Bidner B, Meisinger DJ, McKeith FK. Measuring pork color: effects of bloom time, muscle, $\mathrm{pH}$ and relationship to instrumental parameters. Meat Sci. 2001:57:169-76.

37. Commission Internationale de l'Eclairage (CIE). Recommendations on uniform color spaces-color difference equations, psychometric color terms. Supplement no. 2 to CIE Publication No. 15 (E-1.3.1) 1971/(TC-1-3), Paris; 1978.

38. Martin AH, Fredeen HT, L'Hirondelle PJ, Murray AC, Weiss GM. Pork quality attributes: their estimation and their relationships with carcass composition in commercial pigs. Can J Anim Sci. 1981:61:289-98.

39. Dransfield E, Nute GE, Morttram DS, Rowan TG, Lawrence TLJ. Pork quality from pigs fed on low glucosinate rapeseed meal: influence of level in the diet, sex and ultimate pH. J Sci Food Agri. 1985;36:546-56.

40. DeVol DL, McKeith FK, Bechtel PJ, Novasakofski J, Shanks RD, Carr TR Variation in composition and palatability traits and relationships between muscle characteristics and palatability in a random sample of pork carcasses. J Anim Sci. 1988;66:385-95.

41. Bidner BS, Ellis M, Miller KD, Hemann M, Campion D, McKeith FK. Effect of the $R N$ gene and feed withdrawal prior to slaughter on fresh Longissimus quality and sensory characteristics. J Anim Sci. 1999;77(Suppl I):49.

42. Howard A, Lawrie RA. Spec. Rept. Fd. Invest. Bd., Lond., No. 63. In: Lawrie RA Ledward DA, editors. Lawrie's meat science. 7th edition. Cambridge, UK: Wood head Publishing: 1956. p. 310

43. Marsh BB, Lochner JV, Takahashi G, Kragness DD. Effects of early postmortem $\mathrm{pH}$ and temperature on beef tenderness. Meat Sci. 1981;5:479-83. 